\title{
ESTIMATING PEAK FLOW-DISCHARGE DURING EXTREME RAINFALL EVENTS FOR THE GAO-PING RIVER, TAIWAN
}

\author{
J.-C.CHEN ${ }^{1}$, C.YANG ${ }^{2} \&$ J.CHING ${ }^{2}$ \\ ${ }^{1}$ Department of Environmental \& Hazards-Resistant Design, Huafan University, Taiwan. \\ ${ }^{2}$ Department of Civil Engineering, National Taiwan University, Taiwan.
}

\begin{abstract}
Typhoon Morakot struck central and southern Taiwan on August 8, 2009. The high intensity and accumulation of rainfall induced floods, landslides and debris flows. During Typhoon Morakot, the flood level was beyond the design limit of many river embankments in southern Taiwan. It is, therefore, desirable to estimate the peak flow-discharge for similar extreme rainfall events in future. In this study, the destructive flood in the Gao-ping river in southern Taiwan, caused by Typhoon Morakot, was selected as an area for case analysis. First, hydrological and geomorphological data for historical typhoons together with rainfall data were collected and analyzed. Next, the rational method, combined with a number of equations, was proposed to estimate peak flow-discharges in the river produced by extreme rainfall events. The estimated peak flow-discharges of historical events were then compared with the observation data acquired from stream gauge stations and previous studies. The results showed that the proposed method is able to estimate the flow-discharge in the Gao-ping river with reasonable accuracy if the flow rate of interest is greater than $5000 \mathrm{cms}$ or the return period of interest is more than 100 years. It could, therefore, be used to determine the peak flow-discharge for extreme rainfall events. Keywords:extreme rainfall events, peak flow-discharge, rational method, Typhoon Morakot.
\end{abstract}

\section{INTRODUCTION}

The peak flow-discharge is an important variable when designing flood mitigation structures such as culverts, flumes, bridges, revetments, and dams. The unit hydrograph and rational methods are common ways to determine the peak discharge in hydrological analysis. Generally, the unit hydrograph method is used when long-term hydrological data for a river is available. The rational method, an empirical equation proposed by Kuichling [1], was widely used to estimate peak flows from urban and small rural un-gauged catchments [2]. The main advantage of the rational method is that there is ample experience in its application over many years of its use [3]. It also adopts a simple concept and can be computed without the use of computers. However, much of the literature indicates that the rational method is appropriate only for small catchments and the definition of a 'small catchment' is not consistent among practitioners. For example, the catchment area (A) limit is $0.08 \mathrm{~km}^{2}$ in New York [4, 5], $25 \mathrm{~km}^{2}$ in rural Australia [6], and $10 \mathrm{~km}^{2}$ in Taiwan [7]. The accuracy of the peak discharge determined by the rational method could be uncertain when A exceeds its limit. Many streams or rivers in mountainous areas usually lack stream gauge stations or have no flow-rate data record. Even if stream gauge stations were installed, these stations have a high possibility of being destroyed by massive floods during extreme events. The flooding induced by the extreme 


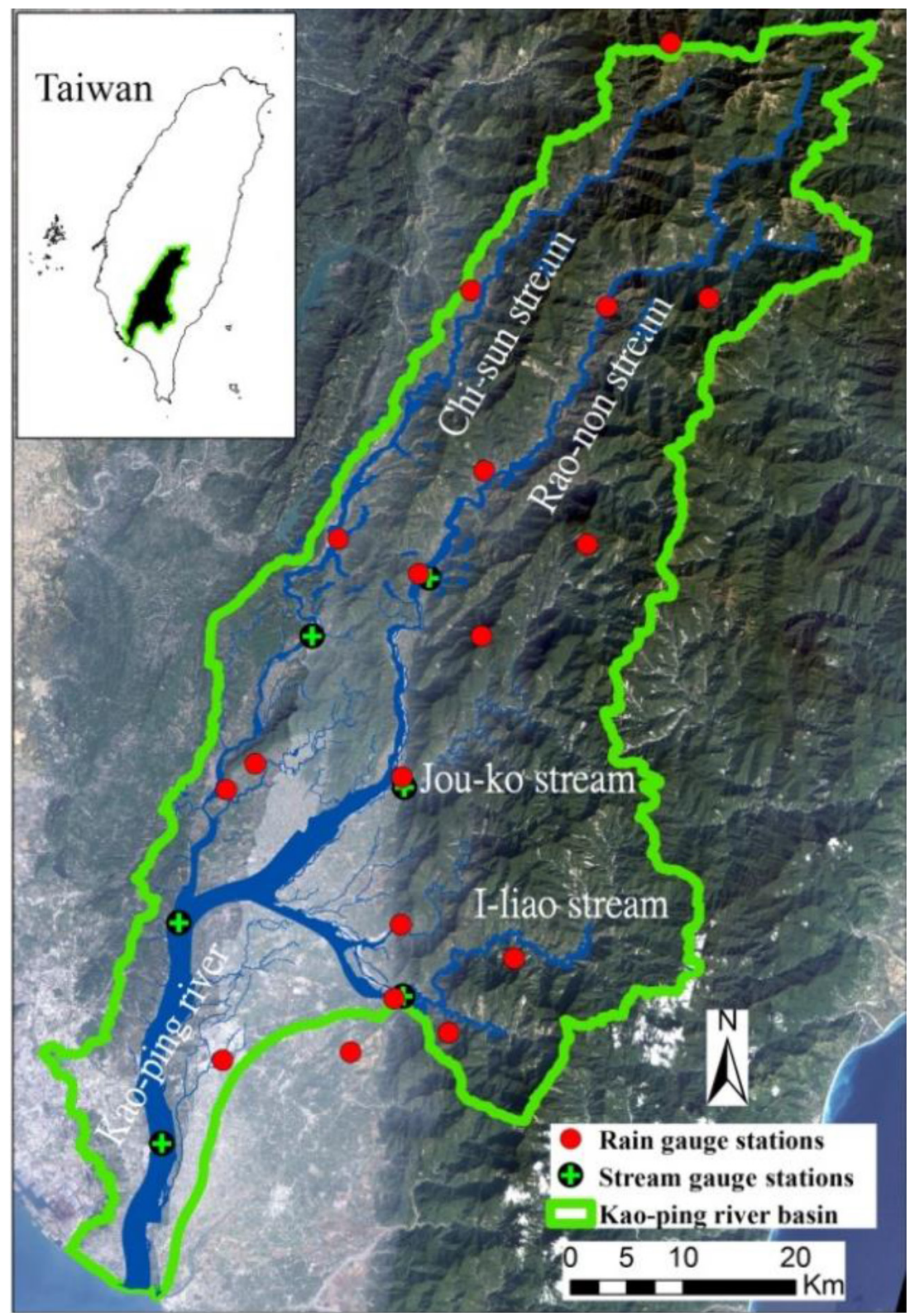

Figure 1: Map showing 18 rain gauge stations and 6 stream gauge stations in the study area of the Gao-ping river catchment.

rainfall during Typhoon Morakot is an example of a huge flood that took place in southern Taiwan in 2009. During this extreme rainfall event, most stream gauge stations were destroyed or were unable to operate normally. Due to the fact that the peak flow discharge is an important hydrologic parameter in hazard prevention and hydraulic engineering design, especially for extreme rainfall events, the rational method was used to examine its reasonability in the 
analysis of peak flow discharge. The Gao-ping river, located in southern Taiwan, was selected as the study area. The peak flow discharge in the river produced by historical rainfall events were estimated by the rational method and they were compared with observation data. The estimated peak flow-discharge was also compared with previous studies.

\section{STUDY AREA}

The study area is located in the Kao-ping river basin of southern Taiwan. The river has a catchment area of $3342 \mathrm{~km}^{2}$ and includes four streams: the Rao-non stream, Jou-ko stream, I-liao stream, and Chi-sun stream. There are 18 rain gauge stations and 6 stream gauge stations in the basin. The six stream gauge stations are with names: Da-Jing bridge (DJB), Shin-Fa bridge (SFB), Sun-Di-Men (SDM), Li-Lin bridge (LLB), Sun-Lin bridge (SLB), and Wan-Da bridge (WDB), as shown in Fig. 1. The hourly rainfall and flow discharge data taken from the rain and stream gauge stations during the Typhoon events that occurred from 2004 to 2009 were collected and used to analyze the rainfall intensity and peak flow discharge.

\section{METHOD}

\subsection{Equations}

\subsubsection{Rational method}

The rational method has been used for over 150 years and remains the most widely used method for estimating peak flows from urban and small rural un-gauged catchments[2]. It relates peak flow discharge, $\mathrm{Q}\left(\mathrm{m}^{3} / \mathrm{s}\right)$, to the catchment area, A (ha), rainfall intensity, I $(\mathrm{mm} / \mathrm{h})$, and runoff coefficient, $\mathrm{C}$. The equation has the form:

$$
\mathrm{Q}=\mathrm{CIA} / 360
$$

This equation is also generally used to determine the peak discharge for water flow in mountainous gullies $[7,8]$ or the watershed where there is a lack of hydrological observation data. This is because it is a simple equation and all the parameters involved can be easily obtained. The method is based on the assumptions that the rainfall intensity and storm duration is uniform over the study area, that the storm duration must be equal to the time of concentration of the catchment, and that the runoff coefficient must be constant during the storm [9].

The runoff coefficient $C_{i}$ is a dimensionless parameter that represents the percentage of rainfall appearing as runoff. $\mathrm{C}$ includes interception, infiltration, evaporation, depression storage, and groundwater flow in the hydrological cycle and it depends on soil type, land use, degree of imperviousness, watershed slope, surface roughness, antecedent moisture condition, and so on. A suggested range of runoff coefficients are available in many papers and handbooks. The average runoff coefficients for various surface types are commonly used. The average runoff coefficient $\mathrm{C}$ for a catchment was determined in this paper by the following equation:

$$
\mathrm{C}=\frac{1}{\mathrm{~m}} \sum_{\mathrm{j}=1}^{\mathrm{m}} \mathrm{C}_{\mathrm{j}}
$$

in which, the catchment area was divided into m number of units, following the land use and landform. The runoff coefficient for each unit $\mathrm{C}$ was determined by referring to the handbooks of SWCB [7] for Taiwan. 


\subsubsection{Average rainfall intensity}

The rainfall intensity is the volume of rain that has fallen per unit of time. The rainfall intensity varies with time during a given storm for different geographical regions and also for different locations within these regions, resulting in different rainfall distributions [3, 10]. The reciprocal-distance-squared method [11] was used to determine the average rainfall for a catchment. Since this method is simple and can directly reflect the distance weighting, it has been widely used in determining un-gauged or regional average rainfalls [12]. The average rainfall intensity I estimated by the reciprocal-distance-squared method can be expressed as follows:

$$
\mathrm{I}=\sum_{\mathrm{i}=1}^{\mathrm{N}} \mathrm{w}_{\mathrm{i}} \mathrm{I}_{\mathrm{i}}
$$

in which

$$
\mathrm{w}_{\mathrm{i}}=\left(\frac{1}{\mathrm{~d}_{\mathrm{i}}^{2}}\right)\left(\sum_{\mathrm{i}=1}^{\mathrm{N}} \frac{1}{\mathrm{~d}_{\mathrm{i}}^{2}}\right),
$$

where $\mathrm{N}$ is the number of gauge stations; $\mathrm{I}_{\mathrm{i}}$ is the rainfall intensity at the ith gauge station; $\mathrm{w}_{\mathrm{i}}$ is the weighting factor corresponding to the ith gauge station; $d_{i}$ is the distance from the ith gauge station to the center of the chosen catchment.

\subsubsection{I-D curve and Horner formula}

The analysis of $I_{i}$ in this paper is divided into two parts. Part one focuses on rainfall events and the value of $I_{i}$ is determined from the relationship between the maximum rainfall intensity and its duration (the I-D curve). Part 2 focuses on the design rainfall and $\mathrm{I}_{\mathrm{i}}$ is determined from the Horner formula [13]. The rainfall intensity can be read from the I-D curveand from the Horner formula at the chosen catchment, for a duration equal to the time of concentration. To obtain the design rainfall intensity at each rain gauge station, thedesign rainfall formula for the study area was collected. The rainfall-duration-frequency curve at each rain gauge station was collected to determine the design rainfall intensity and the rainfall intensity for a return period. The design rainfall intensity in this paper was expressed by a form of the Horner formula:

$$
\mathrm{I}_{\mathrm{i}}=\mathrm{a} /(\mathrm{D}+\mathrm{b})^{\mathrm{c}}
$$

where $I_{i}$ is the rainfall intensity $(\mathrm{mm} / \mathrm{h})$ at a gauge station; D is rainfall duration (min); $a, b$, and $c$ are empirical coefficients that depend on the rainfall characteristics of the area and vary with the return period of rainfall. The rainfall intensity at various return periods, such as 2,5 , $10,25,50,100$, and 200 years, were determined by the above equation according to the coefficients a, b, and c, developed by WRA[14].

\subsubsection{Time of concentration}

The time of concentration is defined as the travel time for the runoff to move from the most hydraulically remote point of the contributing catchment area to the point where peak flow is estimated. The time of concentration, tc, is equal to the sum of the overflow time, t1 (the travel time from the most remote point to the channel inlet), and the channel flow time, $\mathrm{t} 2$ (the travel time in channels to the catchment outlet). It can be determined using empirical formulas, such as Kirpich's equation, Kerby's equation, or the kinematic wave equation, and also from hydrographs [15] and technical handbooks [7]. The empirical equation for tc (in min) used in Taiwan [7] can be expressed as: 


$$
\mathrm{tc}=\mathrm{l} /(60 \mathrm{v})+5 \mathrm{~L}(\mathrm{~L} / \mathrm{H})^{0.6} / 6,
$$

in which, $1(\mathrm{~m})$ is the overflow length, $\mathrm{v}$ is the overflow velocity (generally ranging from 0.3 to $0.6 \mathrm{~m} / \mathrm{s}), \mathrm{L}(\mathrm{km})$ is the stream length, and $\mathrm{H}(\mathrm{km})$ is the elevation difference across the stream length.

\subsection{Procedure}

\subsubsection{Select a catchment area form a point of interest and calculate} the concentration time

First, we have to select a catchment area from a point of interest and calculate the concentration time. The point is taken from a stream gauge station that has recorded flow-discharge observation data. For example, the catchment area of the Jou-Ko stream at the DJB station is $374 \mathrm{~km}^{2}$. The catchment area covered 13 rain gauge stations. The concentration time, tc, at the DJB station is $327 \mathrm{~min}$, using eqn(6).

\subsubsection{Determine the rainfallintensity for a rain gauge station}

A relationship was developed between the maximum rainfall intensity and duration (the I-D curve) at each rain gauge station for a rainfall event. For example, the I-D curve for one of the rain gauge stations, the Mei-Long (ML) station in the Jou-Ko stream catchment, during Typhoon Conson, is shown in Fig. 2. The maximum rainfall intensity $\mathrm{I}_{\mathrm{i}}$ is $5.27 \mathrm{~mm} / \mathrm{h}$, taken from the I-D curve at tc $=327 \mathrm{~min}$. Following the same procedure as above, the $\mathrm{I}_{\mathrm{i}}$ value for

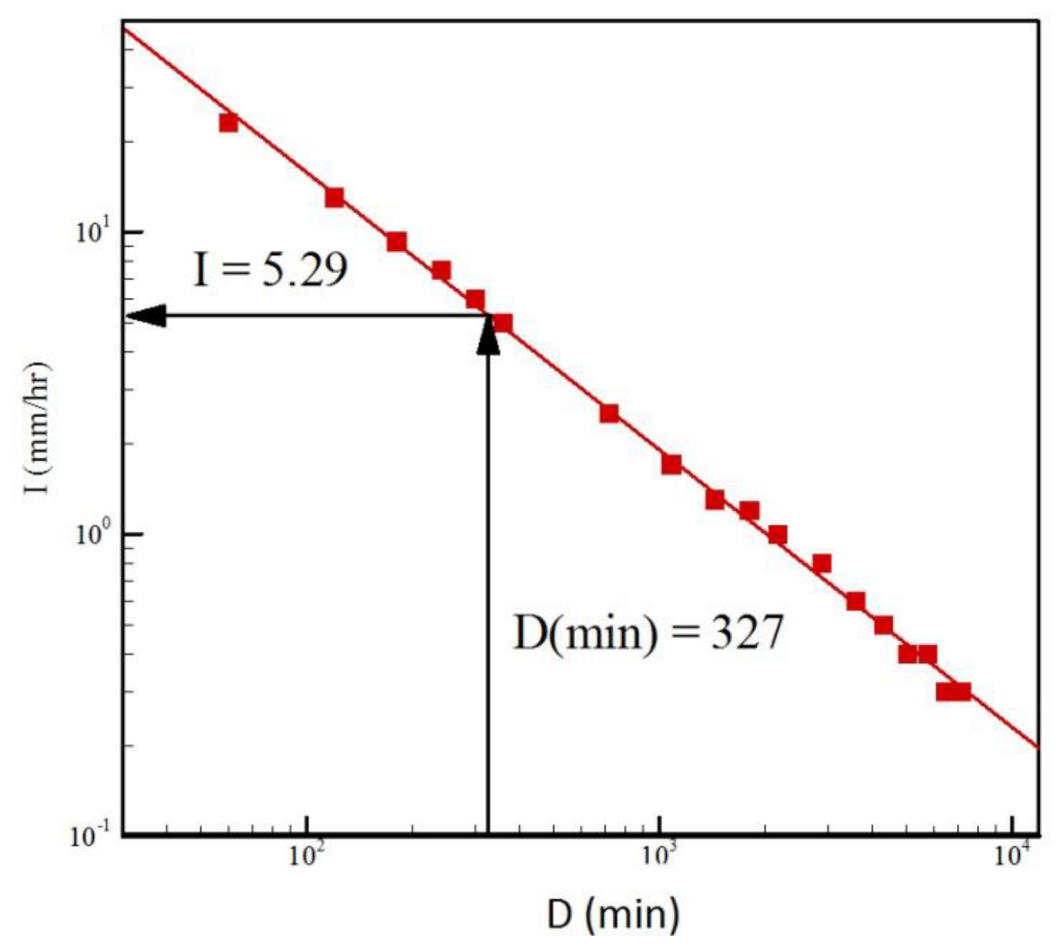

Figure 2: Relationship between the maximum rainfall intensity I and the duration D in the case of the Mei-Long rain gauge station during Typhoon Conson. 
the other 12 rain gauge stations in the catchment of the Jou-Ko stream can be determined. In order to obtain the design rainfall intensity at each rain gauge station, the Horner formula eqn(5) for the study area was obtained to determine the rainfall intensity for a return period.

\subsubsection{Determine the average rainfallintensity in a catchment}

The weighting factor $\mathrm{w}_{\mathrm{i}}$ for an individual rain gauge station can be obtained using eqn(4) when the central point of the watershed is determined. In the example of the Jou-Ko stream catchment during Typhoon Conson, there are 13 gauge stations and the average rainfall intensity I can be evaluated from eqn(3). The resulting I is $4.21 \mathrm{~mm} / \mathrm{h}$.

\subsubsection{Calculate the peak discharge}

Finally, the peak discharge can be obtained using the rational equation (eqn1). The resulting $\mathrm{Q}$ is $299 \mathrm{cms}$, obtained with $\mathrm{I}=4.21 \mathrm{~mm} / \mathrm{h}, \mathrm{C}=0.68$, and $\mathrm{A}=37,600$ ha for the Jou-Ko stream watershed during Typhoon Conson.

\section{RESULTS}

\subsection{Comparison with measured data}

The measured flow discharges collected from six stream gauge stations [16], Da-Jing bridge (DJB), Sin-Fa bridge (SFB), Sun-Di-Men (SDM), Sun-Lin bridge (SLB), Li-Lin bridge (LLB), and Wan-Da bridge (WDB), during 15 typhoon events that occurred from 2004 to 2008 are shown in Fig. 3. These measured flow discharges are then used as a comparison with

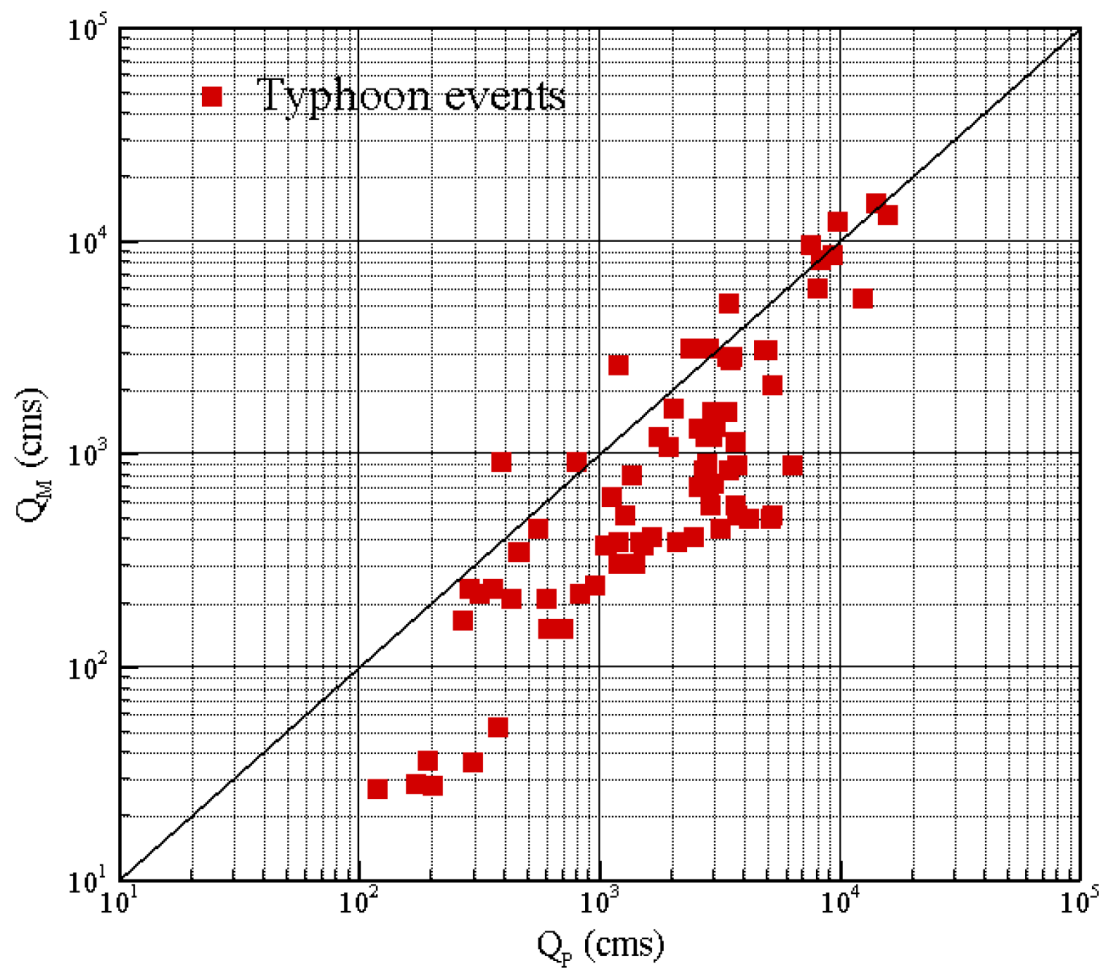

Figure 3:Measured flow discharge $\mathrm{Q}_{\mathrm{M}}$ and the estimated flow discharge $\mathrm{Q}_{\mathrm{P}}$ 
the flow discharge estimated by the method proposed in this study. Figure 3 shows that most of the estimated discharges, $\mathrm{Q}_{\mathrm{P}}$, are greater than the measured discharge, $\mathrm{Q}_{\mathrm{M}}$, that is, $\mathrm{Q}_{\mathrm{M}}<\mathrm{Q}_{\mathrm{P}}$, when $\mathrm{Q}_{\mathrm{M}}<5000 \mathrm{cms}$. At higher discharge, $\mathrm{Q}_{\mathrm{M}}>5000 \mathrm{cms}, \mathrm{Q}_{\mathrm{P}}$ is close to $\mathrm{Q}_{\mathrm{M}}$.

\subsection{Comparison with previous studies on discharge design}

The design peak discharges at return periods of 2, 10, and 100 years were determined by the method proposed in this study for the Kao-ping river basin. This result was then compared with the official result determined using the dimensionless unit hydrograph [14, 17], as shown in Table 1 and Fig. 4. For some data obtained for discharges smaller than $5000 \mathrm{cms}$ or with return periods $T<100$ years, the estimated discharge produced by this study $\left(Q_{P}\right)$ is greater than the official WRA estimated discharge (Qc). For higher design discharges, exceeding $5000 \mathrm{cms}$, or return periods $\mathrm{T}$ of more than 100 years, $\mathrm{Q}_{\mathrm{P}}$ is close to $\mathrm{Q}_{\mathrm{C}}$. Here, we also find that the catchment areas in Table 1 are much greater than those from previous researchers [4-7].

\subsection{Estimation of peak flow discharge during Typhoon Morakot}

Typhoon Morakot brought extreme rainfall and caused many hazards, such as landslides, debris flows, and floods, in southern and central Taiwan [18]. For such extreme rainfall, most flow discharge stations could not work and, as a result, there was no recorded data for the Gao-ping river in southern Taiwan. Due to the fact that the actual flow discharge

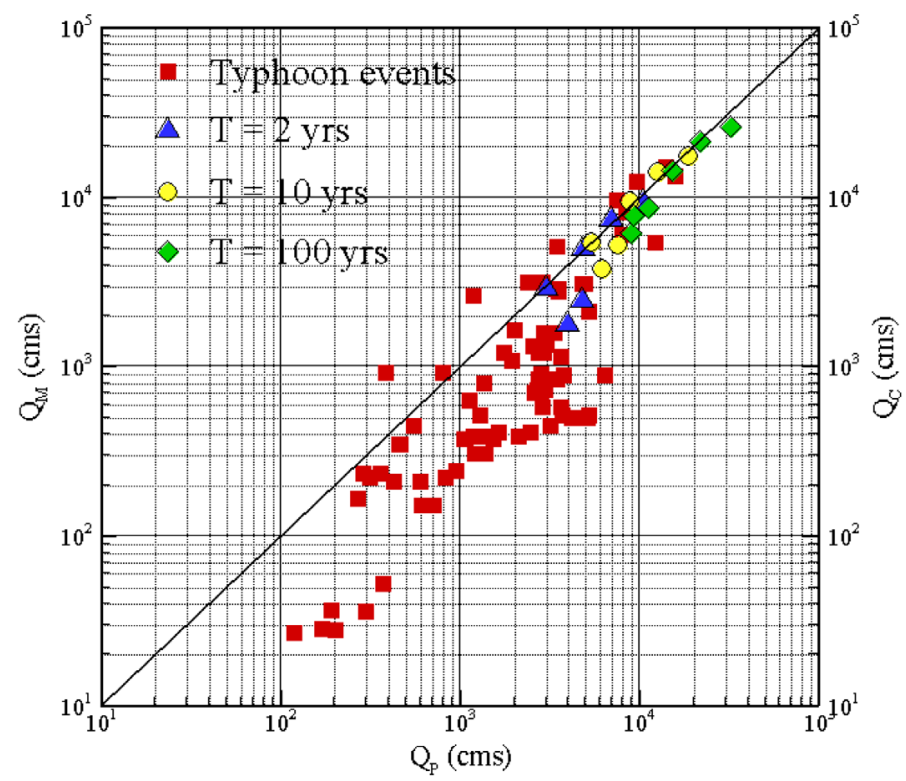

Note: $\mathrm{Q}_{\mathrm{M}}=$ measured flow discharge in historical typhoon events; $\mathrm{Q}_{\mathrm{P}}=$ estimated flow discharge in this study; $\mathrm{Q}_{\mathrm{C}}=$ estimated official flow discharge

Figure 4: Flow discharge estimated from the method proposed in this study $\left(\mathrm{Q}_{\mathrm{P}}\right)$ compared with that measured at flow discharge stations during various typhoon events $\left(Q_{M}\right)$, and that determined from previous studies $\left(\mathrm{Q}_{\mathrm{C}}\right)$. 


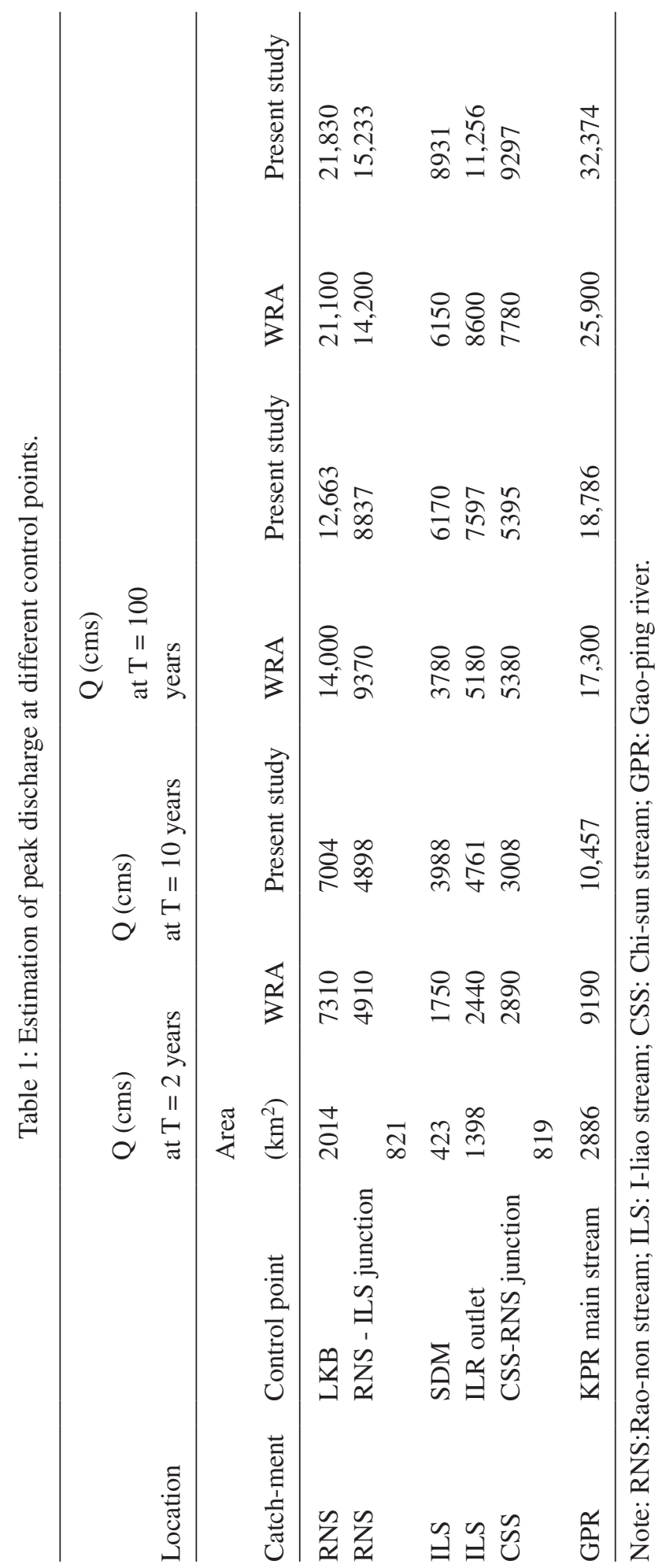


is important in hazard prevention and hydraulic engineering design, especially for extreme rainfall events, researchers evaluated the peak discharge using a hydrological model. For example, the peak flow discharge at some flow discharge stations (SDM, $\mathrm{SFB}, \mathrm{DJB}$ ) in the Gao-ping river were determined using the unit hydrograph method [16, 19]. The estimated peak flow discharge from previous studies [16, 19] are compared with the peak flow discharge estimated by the method proposed in this study, as shown in Fig. 5. Figure 5 shows that the estimated flow discharge in this study $\left(Q_{P}\right)$ agrees with those estimated in previous studies $\left(\mathrm{Q}_{\mathrm{C}}\right)$. The methods used in previous studies differ from the present study. The design discharges from previous studies were all determined by the unit hydrograph method, with different periods of rainfall and discharge data. The method proposed in this study can easily determine the discharge without a long-term flow rate record. Many streams or rivers in mountainous areas generally have a lack of stream gauging stations or have no flow-rate data record. This means that the method proposed in this study maybe used to estimate the design discharge due to extreme rainfall for an area with a lack of historical rainfall or discharge data. However, this study only focuses on the Gao-ping river area and on typhoon events; therefore, future studies are needed for other areas and rainfall conditions.

\section{CONCLUSIONS}

The peak discharges for a rainfall event and various return periods were determined using the rational method combined with some equations that were proposed in this paper. The estimated peak discharge was compared with measured data and those from previous studies.

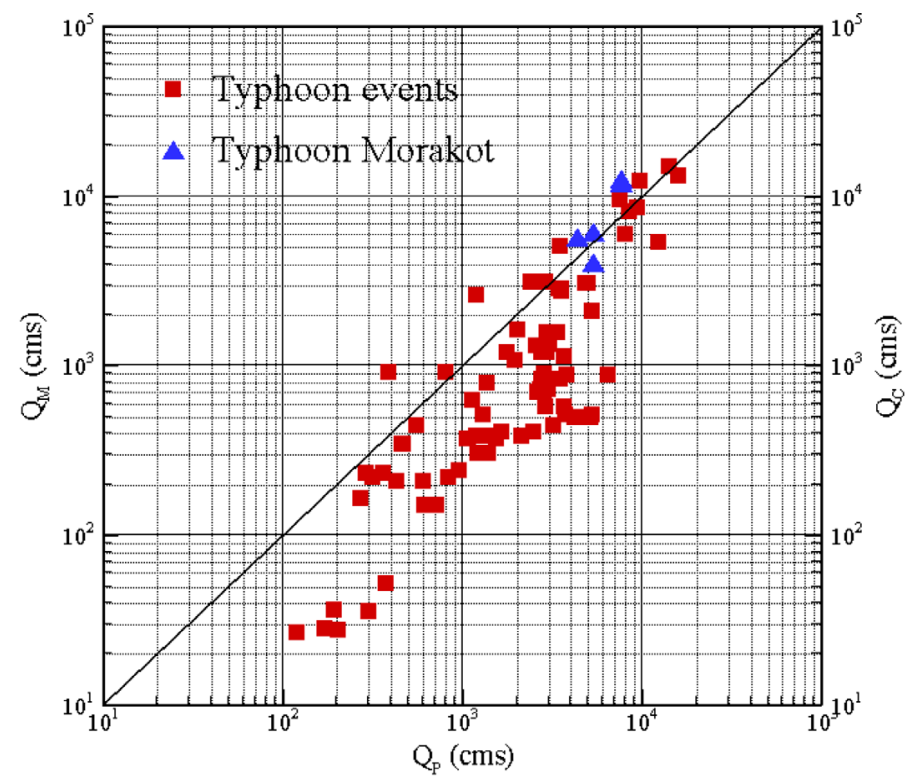

Note: $\mathrm{Q}_{\mathrm{M}}=$ measured flow discharge in historical typhoon events; $\mathrm{Q}_{\mathrm{P}}=$ estimated flow discharge in Typhoon Morakot in this study; $\mathrm{Q}_{\mathrm{C}}=$ estimated official flow discharge during Typhoon Morakot

Figure 5:Flow discharge estimated from the method proposed in this study $\left(\mathrm{Q}_{\mathrm{P}}\right)$ compared with those measured at flow discharge stations $\left(Q_{M}\right)$ and from previous studies $\left(Q_{C}\right)$ during Typhoon Morakot. 
Results showed that the estimated peak discharge is greater than the measured data and those of previous studies for low flow-discharges, Q $<5000 \mathrm{cms}$, or for return periods of $\mathrm{T}<100$ years. The estimated peak discharge is in agreement, however, with the measured data and those of previous studies at high flow discharge, where $\mathrm{Q}>5000 \mathrm{cms}$, or with $\mathrm{T}>100$ years. The peak discharges in the Gao-ping river that were brought on by Typhoon Morakot, the extreme rainfall event discussed in this study, were determined by the rational method, and these were found to be close to the results of previous works using the unit hydrograph method. The rational method could be used to determine the peak discharge brought on by extreme rainfalls, or rainfall with $\mathrm{T}>100$ years. The main advantage of the rational method is that it is a simple concept, computed without the use of computers, and it is available for streams without stream gauge stations. However, this study only focuses on the Gao-ping river area and on typhoon events; therefore, future studies are needed for other areas and rainfall conditions.

\section{REFERENCES}

[1] Kuichling, E. \& Hering, R., TheRelation Between the Rainfall and the Discharge of Sewers in Populous District, American Society of Civil Engineers: New York, 20, pp. $1-56,1889$.

[2] Watts, L.F. \& Hawke, R.M., The effects of urbanization on hydrologic response: a study of two coastal catchments. Journal of Hydrology, 42(2), pp. 125-143, 2003.

[3] OPW, Flood StudiesUpdate Programme:Flood Estimation in Small and Urbanized Catchments, Hydrology and Coastal Section, Office of Public Works (OPW), 2012.

[4] NYS, Standards and Specifications for Erosion and Sediment Control, New York State(NYS), 2004.

[5] Debo, T.N. \& Reese, A., Municipal Storm Water Management, p. 209, 1995.

[6] QG, Queensland Urban Drainage Manual, Vol. 1, 2nd ed., Queensland Government (QG), 2007.

[7] SWCB, Technical Handbook of Soil and Water Conservation, Soil and Water Conservation Bureau (SWCB), Council of Agriculture, Executive Yuan, Taiwan, 2003.(in Chinese)

[8] Chen, J.C., Jan, C.D.\&Lee, M.S., Reliability analysis of design discharge for mountainous gully flow.Journal of Hydraulic Research, 46(6), pp. 835-838, 2008. http://dx.doi.org/10.3826/jhr.2008.3173

[9] Hays, D.C.\& Young, R.L., Comparison of peak discharge and runoff characteristicestimates from the rational method to field observations for small basins in central Virginia. USGS Scientific Investigations Report, 2005-5254, 2006.

[10] Nyman, D., Hydrology Handbook forConservation Commissions, MassachusettsDepartment ofEnvironmental Protection, 2002.

[11] Chow, V.T., Maidment, D.R.\&Mays, L.W., Applied Hydrology. McGraw-Hill: Singapore, 1988.

[12] Chen, J.C., Jan, C.D. \&Huang, W.S., Characteristics of rainfall triggering of debris flows in the chenyulanwatershed, Taiwan.Natural Hazards and Earth System Sciences, 13, pp. 1015-1023, 2013. http://dx.doi.org/10.5194/nhess-13-1015-2013

[13] Horner, W.\&Flynt, F., Relation between rainfall and runoff from small urban areas. Trans.ASCE,101,pp. 104-183, 1936. 
[14] WRA, Technique of Hydrological Observation and Criteria of Hydrological Analysis, Water Resources Agency (WRA), Ministry of Economic Affairs, Taiwan, 2011(in Chinese)

[15] Chin, D.A.,Water-Resources Engineering, Prentice-Hall, 2000.

[16] WRA, Planning on Gao-ping river treatment, Lab. of Hydraulic planning, Water Resources Agency (WRA), Ministry of Economic Affairs, Taiwan, 2008(in Chinese)

[17] WRA, Analysis on extreme rainfall and flow discharge in Typhoon Morakot, Water Resources Agency (WRA), Ministry of Economic Affairs, Taiwan, 2009(in Chinese)

[18] Chen, J.C. \& Chuang, M.R., Discharge of landslide-induced debris flows: case studies of Typhoon Morakot in Southern Taiwan.Natural Hazards and Earth System Sciences, 14, pp. 1719-1730, 2014.

http://dx.doi.org/10.5194/nhess-14-1719-2014

[19] SEC, Investigation on the 88 flood, Sinotech Engineering Consultants (SEC), Inc., Taiwan, 2009 (in Chinese) 